\title{
Research on the Two-way Linkage Development Mechanism Between Guangdong, Hong Kong, Macao Bay Area and Guangdong Free Trade Zone*
}

\author{
Jiayi Zhong \\ Guangzhou College of Technology and Business \\ Guangzhou, China 510850
}

\author{
Aihua Zhu \\ Guangzhou College of Technology and Business \\ Guangzhou, China 510850
}

\begin{abstract}
The development plan of Guangdong, Hong Kong and Macao Bay Area is going be launched soon, and the construction of Guangdong Free Trade Zone will continue to advance. Guangdong faces the dual national strategic and policy advantages of the Bay Area and the Free Trade Zone in the "One Belt and One Road" construction process. Bay Area and the Free Trade Zone are the point-to-face relationship. The pilot use of the red line of the Free Trade Zone policy function as a test of Institutional innovation in the free trade zone. When the conditions are mature, this practice will be copied and promoted to the Bay Area to drive the "big breakthrough" with "small incision". On the other hand, as a high-level regional economy, a national comprehensive reform pilot zone, and a "One Belt and One Road" support node ,Guangdong, Hong Kong and Macao Bay Area can promote a new round of institutional innovation in the free trade zone, optimize the free trade zone business. The environment and the innovation of the Guangdong Free Trade Zone and the cooperation model of Hong Kong and Macao will seize the opportunities and enhance the development potential of the free trade zone. Under this development background, Guangdong should grasp the historical opportunity of the twoway linkage development of Great Bay area and the Free Trade Zone, deepen the "One Belt and One Road" international space, and gradually improve the right to speak in the global economic governance structure.
\end{abstract}

Keywords-Guangdong; Hong Kong and Macao Bay Area; Guangdong Free Trade Zone; linkage development; system innovation

\section{INTRODUCTION}

The major strategy of Guangdong, Hong Kong and Macao Bay Area is to create an upgraded version of the Pearl River Delta urban agglomeration including Hong Kong and Macao. The Bay Area is in a critical period of economic and industrial transformation. It has gradually formed a twowheel drive industrial system of advanced manufacturing and modern service industry. It will become an important engine leading the economic growth in China and the world. It will also be an important source of knowledge innovation, institutional reform, new technology and application. The Bay Area shoulders the historical responsibility of exploring

*Fund Project: 2018 Project of the 13th Five-Year Plan of Philosophy and Social Science in Guangzhou city (2018GZGJ148). new modes of regional cooperation and opening up. The development of the Bay Area will inject new vitality into the further development of the Guangdong Free Trade Zone. At the same time, the free trade pilot zone in China has formed a "1+3+7" pattern, and institutional innovation is the main mission of the free trade zone. The Guangdong Free Trade Zone will take the lead in benchmarking the international investment and trade rules in the country, and establish an institutional system compatible with the international shipping hub, the international trade center and Financial industry opening up trial demonstration window. The Free Trade Zone needs to further strengthen the linkage with the national strategy of the Bay Area, carry out differentiated pilot tasks, conduct systematic institutional innovation and experimentation around the key areas and difficult issues of the integration of the Bay Area, form more reform pilot experience for replication and promotion on this basis. The reform and pilot experience of reform and promotion has become the core support point for the coordinated development of the urban agglomeration of Guangdong, Hong Kong and Macao Bay Area. It can be said that the construction of the Bay Area and the Free Trade Zone is an strategic move of the country. How to achieve coordinated development is of great importance to the comprehensive reform of the region and the construction of the free trade zone, and even the major strategic deployment of the Free Trade Port.

\section{DEVELOPMENT OF ForEIGN TRADE IN THE BAY AREA OF GUANGDONG, HONG KONG AND MACAO}

From 2012 to 2017, the total foreign trade volume of nine Cities (excluding Hong Kong and Macao) in the Bay Area showed a trend of increasing first, then falling and then rising. The total import and export volume increased from 5.96 trillion yuan in 2012 to 6.51 trillion yuan in 2013. It accounted for $95.9 \%$ of Guangdong's total foreign trade, and then fell back year by year and fell to 6.01 trillion yuan in 2016, accounting for $95.3 \%$ of the province. In 2017, the import and export of the nine cities in Bay Area reversed the previous three-year decline, with an annual growth rate of $8.2 \%$. The total amount rebounded to 6.51 trillion yuan, accounting for $95.07 \%$. The nine cities of Guangdong, Hong Kong and Macao represents the most economically 
developed region in Guangdong Province. The total foreign trade accounts for more than $95 \%$ of the province's total, the status of foreign trade is evident.

TABLE I. IMPORT AND EXPORT OF NINE CITIES IN BAY AREA

\begin{tabular}{|c|c|c|c|c|}
\hline City & $\begin{array}{c}\text { Total foreign import and } \\
\text { export trade value in } 2012 \\
\text { (100 million yuan) }\end{array}$ & $\begin{array}{l}\text { Total foreign import } \\
\text { and export trade value in } \\
2017 \text { (100 million yuan) }\end{array}$ & $\begin{array}{c}\text { Foreign trade in Guangdong } \\
\text { accounted for the proportion of } \\
\text { Guangdong Province in } 2017(\%)\end{array}$ & $\begin{array}{c}\text { 2012-2017 Guangdong's nine cities to } \\
\text { Hong Kong and Macao's foreign } \\
\text { trade development }\end{array}$ \\
\hline Guangzhou & 7397.6 & 9714.4 & 14.3 & \multirow{5}{*}{$\begin{array}{l}\text { Hong Kong: The total value of imports } \\
\text { and exports has decreased from } 1.4 \\
\text { trillion to } 1.12 \text { trillion. Processing trade } \\
\text { has declined slightly year by year, and } \\
\text { the proportion of general trade has been } \\
\text { increasing. }\end{array}$} \\
\hline Shenzhen & 30340 & 28000 & 41.1 & \\
\hline Dongguan & 9124 & 12264.4 & 18 & \\
\hline Huizhou & 3125.6 & 3416 & 5.03 & \\
\hline Foshan & 3854.9 & 4357.4 & 6.4 & \\
\hline Jiangmen & 1184.7 & 1385.2 & 2.04 & \multirow{4}{*}{$\begin{array}{l}\text { Macao: The total value of imports and } \\
\text { exports increased from } 11.54 \text { billion } \\
\text { yuan to } 15.12 \text { billion yuan, and exports } \\
\text { increased significantly, expanding by } \\
41.8 \% \text {. }\end{array}$} \\
\hline Zhongshan & 2116.4 & 2581.5 & 3.8 & \\
\hline Zhuhai & 2884.1 & 2990.1 & 4.4 & \\
\hline Zhaoqing & 412 & 511.4 & $0.5 \%$ & \\
\hline
\end{tabular}

a. Source: Guangdong, Hong Kong and Macao Bay Area Construction Report (2018), Guangdong Statistical Yearbook (2012-2017)

It can be seen that the two first-tier cities of Guangzhou and Shenzhen occupy more than $50 \%$ of the total foreign trade of Guangdong Province. In particular, Shenzhen is a frontier city for reform and opening up, it is adjacent to Hong Kong, its total import and export volume is far ahead of other cities in the Bay Area.

Under the influence of the Hengqin Free Trade Zone, the total volume of imports and exports in Zhuhai has risen slightly, and is expected to maintain steady growth in the future. Foreign trade is the source of regional cooperation in the Bay Area of Guangdong, Hong Kong and Macao. The three major areas of Guangdong Free Trade plays a great role in promoting the integration of the Bay area, the phenomenon of clusters of ports, industries and cities formed by trade will bring an insurmountable superposition effect and synergistic innovation effect to the Bay Area, thus further promoting the expansion of the international trade volume in the Bay Area and creating a virtuous circle.

\section{LEVERAGE THE GUANGDONG FREE TRADE ZONE TO} PROMOTE COMPREHENSIVE REGIONAL REFORM IN THE BAY AREA

According to the State Council's "Deepening the Pilot Free Trade Zone Reform and Opening Program in China (Guangdong)", the Guangdong Free Trade Zone will meet high standards of international economic and trade rules and creat a pioneering zone for an open economy, it will also open a gateway to high-level open ports, and a Cooperation Demonstration Zone of Guangdong, Hong Kong and Macao Bay Area. It can be said that Nansha of Guangzhou, Qianhai of Shenzhen and Hengqin of Zhuhai are the three core support points of the Bay Area. The relationship between the Free Trade Zone and Bay Area is point-to-face. The institutional innovation of the Free Trade Zone, the promotion of mutually beneficial cooperation between the Mainland and Hong Kong and Macao, and the demonstration and leading role of comprehensive opening up to the outside world, have great experimental and reference significance for further deepening reform, opening up and deep integration of Guangdong, Hong Kong and Macao Bay Area. The successful experience of the trade zone can be further replicated and promoted to other cities in the Bay area after the conditions are ripe, with a high starting point to promote the construction of the Guangdong, Hong Kong and Macao Bay Area.

\section{A. Leveraging Guangdong Free Trade Zone to Solve the "123" Problem of Guangdong, Hong Kong and Macao Bay Area}

The biggest advantage of Guangdong, Hong Kong and Macao Bay Area as well as biggest difficulty lies in "one country, two systems, three customs zones". How to coordinate the differences on the basis of one country is a difficult problem for the development of Guangdong, Hong Kong and Macao Bay Area. The central government's positioning for the free trade zone is "for the national trial system, for local development", after more than three years of construction since 2015, the Guangdong Free Trade Zone is already one of the most open areas in the country, the "Free cooperation" "and "Demonstration" is the key to solving the "123" problem. For example, the Nansha Free Trade Zone has introduced a prior ruling on complex taxrelated matters, provided prior ruling services in accordance with laws and related measures, and issued formal tax rulings to avoid tax risks arising from taxpayer policy issues; Hengqin builds a tax integrity report exemption mechanism, encourages taxpayers to initiate honest reports on matters that are uncertain about tax policies, and the tax authorities carry out pre-agreed personalized tax services. At the same time, the Guangdong Free Trade Zone will cooperate with Hong Kong and Macao under the "one country, two systems" and CEPA, in terms of service trade liberalization, industry complementarity, resource sharing and information exchange. Some districts have also implemented the Hong Kong and Macao Residents' taxation policies differently, and the tax efficiency has improved significantly. The Guangdong Free Trade Zone uses the tax instruments in the policy area and actively integrates with the international community in the taxation field. The successful experience is expected to be further promoted throughout the Bay Area of Guangdong, Hong Kong and Macao, greatly alleviating the 
tax system friction between Guangdong, Hong Kong and Macao and promoting tax coordination in the Bay Area.

\section{B. Leveraging Guangdong Free Trade Zone to Promote Financial Innovation in the Bay Area of Guangdong, Hong Kong and Macao}

The future of Guangdong, Hong Kong and Macao Bay Area is a technology plus financial center. Financial cooperation and innovation is an important path to realize the deep integration of financial markets and the cross-border optimization of financial resources in the Bay Area. It is also an inevitable requirement for the implementation of the innovation-driven strategy in the Bay Area. The Guangdong Free Trade Zone has launched a series of important initiatives around the deepening of financial sector open innovation, such as pioneering in the areas of cross-border RMB business innovation and development, financial innovation, investment and financing facilitation of the Guangdong-Hong Kong-Macao service trade liberalization, and financial risk prevention and control system in the Pilot Free Trade Zone. The areas involved have been continuously expanded, and the financial cooperation between Guangdong, Hong Kong and Macao Bay Area has been continuously deepened and strengthened. According to the research results of the Institute of Free Trade Zone of Sun Yat-sen University, Shekou of Shenzhen Area is second only to the Shanghai Pilot Free Trade Zone in terms of financial innovation, ranking second in the country. The three major Free Trade Zones have different positioning in financial cooperation: The main objective of Qianhai is to build a cross-border RMB settlement center under the conditions of RMB capital project's own conversion. It has the only CIPS center in the country outside the head office, and the country's first crossborder transfer of non-performing assets based on the trading platform. Nansha mainly cooperates with shipping-related financial products and services, Hengqin tries to "improve" Hong Kong's experience and then radiate it to the western area of Guangdong Province. The financial innovation index of the three major regions of Guangdong Free Trade Zone ranks in the forefront of the country. The financial innovation and reform pilot policy of the Free Trade Zone is an important starting point for promoting financial cooperation between Guangdong, Hong Kong and Macao Bay Area.

TABLE II. FINANCIAL INNOVATION RANKINGS OF THE FIRST AND SECOND BATCH OF PILOT FREE TRADE ZONES

\begin{tabular}{clc}
\hline Ranking & Area & Index \\
$\mathbf{1}$ & Shanghai & 85.55 \\
$\mathbf{2}$ & Qianhai & 84.04 \\
$\mathbf{3}$ & Tianjin & 79.81 \\
$\mathbf{4}$ & Nansha & 77.17 \\
$\mathbf{5}$ & Hengqin & 76.10 \\
$\mathbf{6}$ & Xiamen & 74.78 \\
$\mathbf{7}$ & Fuzhou & 74.60 \\
$\mathbf{8}$ & Pingtan & 70.48 \\
\hline
\end{tabular}

Source: Institutional Innovation Index of the Institute of Free Trade Zone of Sun Yatsen University (2017-2018)

\section{Leveraging the Guangdong Free Trade Zone to Explore the Construction of Free Trade Port}

In the 19th National Congress of the Communist Party of China, General Secretary Xi Jinping proposed "Giving the Free Trade Pilot Zone greater autonomy in reform and exploring the construction of Free trade port." The construction of Free Trade Port have great significance to the trade facilitation, investment facilitation, coordinated development of Guangdong, Hong Kong and Macao Bay Area and even become a world-class Bay Area. The Free Trade Port is an upgraded version of the Free Trade Zone, it has accumulated a lot of experience. Based on the existing experience and the principle of gradual and orderly progress, it will be piloted from Guangzhou Port and Shenzhen Port, and will be promoted to other areas of the Bay Area when conditions are ripe. The next breakthrough step of the Guangdong Free Trade Zone can be carried out from the "negative list + pre-entry national treatment", the establishment of a comprehensive and unified standard of international trade "single window", the internationalization of financial markets, the consolidation of the rule of law, and the improvement of the post-event supervision mechanism, with reference to the special experience of Singapore and Hong Kong Free Trade Port through the government's continuous decentralization and simplification of administration. The Free Trade Zone will sprint international high standard free trade system, effectively serving the construction of Guangdong, Hong Kong and Macao Bay Area. The BayArea can take advantage of the national strategic opportunity of upgrading the Free Trade Port in the Free Trade Zone, further enhance the synergy between the nine cities of the Pearl River Delta and Hong Kong and Macao, play a good competitive advantage, explore the combined Free Trade Port of Guangdong, Hong Kong and Macao, and boldly innovate Guangdong, Hong Kong and Macao cross-border e-commerce, foreign trade integrated services, offshore trade and other new formats of development mode and supervision mode, so as to achieveFree Trade Port linkage effect, complementary interoperability, misplaced development among Guangdong, Hong Kong and Macao, realize the highest level of trade liberalization and facilitation in the Bay Area .

In addition, the Guangdong Free Trade Zone has great boosting effect on effective flow of elements in the Bay Area of Guangdong, Hong Kong and Macao, expansion of the opening to Hong Kong and Macao, Business environment docking under different systems, strengthening of investment cooperation between Guangdong, Hong Kong and Macao as well as scientific and technological innovation. The Guangdong Free Trade Zone has an important guiding significance for the integrated development and open economy innovation of Guangdong, Hong Kong and Macao Bay Area in all aspects.

\section{Guangdong, Hong Kong and MaCaO Bay AREa BRINGS NEW OPPORTUNITIES FOR THE INNOVATIVE DEVELOPMENT Model of GuANGdong FreE TRAdE ZoNE}

The construction of the Bay Area of Guangdong, Hong Kong and Macao is an important strategic measure to 
comprehensively deepen the mutually beneficial cooperation between Guangdong, Hong Kong and Macao, support the integration of Hong Kong and Macao into the overall situation of national development, respond to the potential threat of new world economic rules, and achieve a high level of openness to the outside world. Guangdong, Hong Kong and Macao Bay Area will become an important engine leading China's economic growth, and become an important platform and market for knowledge innovation and technology application. In the future, a series of strong support measures are expected to be introduced to the Bay Area from the central and local government levels. The Guangdong Free Trade Zone is a point, the Guangdong, Hong Kong and Macao Bay Area is a surface. The point can drive the development of the surface, and the surface can further promote the development of the point. Therefore, under the geographical cooperation advantage, the three major districts of Guangdong Free Trade Zone, which is located in the core area of Guangdong, Hong Kong and Macao Bay Area, will benefit significantly from the new development opportunities brought about by the construction of Guangdong, Hong Kong and Macao Bay Area, the development of which will inject new vitality into the further development of the Guangdong Free Trade Zone.

\section{A. The Construction of Guangdong, Hong Kong, Macao Bay Area Is Conducive to Further Promoting the Innovation of Guangdong Free Trade Zone System}

The driving force for the development of Guangdong, Hong Kong and Macao Bay Area comes from the two-way interaction between "9" (nine cities) and "2" (two areas: Hongkong and Macao) as well as the two-way interaction between Guangdong, Hong Kong and Macao and the country's opening to the outside world and the new dividend brought about by the country's development into a new era. The Bay Area is guided by collaborative innovation with institutional, technological and cultural innovation being the core tenets. In order to build a world-class Bay Area, Guangdong, Hong Kong, Macao Bay Area must reform the key areas and key links, spare no effort to test the system, create new pattern, and carry out institutional innovation and practice from the aspects of government management and market operation. Only by this way can the mechanical and institutional obstacles faced in the process of regional integration be eliminated, thus providing an endless source of support and development for sustainable development Guangdong Free Trade Zone, as the frontier of institutional innovation of Guangdong, Hong Kong and Macao Bay Area can exert institutional innovation advantages, and the "diffusion effect" of institutional innovation in the entire Bay Area will be radiated and diverged to other regions through the Free Trade Zone, driving the reform and innovation in the surrounding areas. Other cities can in turn further promote the institutional innovation of the Free Trade Zone, accumulating institutional advantages and achievements, and form a good situation in which the Bay Area and the Free Trade Zone rise and move side by side. Guangdong, Hong Kong and Macao Bay Area will plan and promote institutional innovation with higher station position, wider vision and greater efforts, which will greatly enhance the quantity and quality of the system innovation in the Free Trade Zone and give full play of the superiority of policy and enthusiasm for reform in the Guangdong Free Trade Zone, pushing the construction of the Free Trade Zone to a higher level and a deeper level.

\section{B. The Construction of the Guangdong, Hong Kong and Macao Bay Area Is Conducive to Further Optimizing the Business Environment of the Guangdong Free Trade Zone}

It is an inevitable requirement to promote the formation of an internationally competitive business environment in Guangdong, Hong Kong and Macao Bay Area in order to lead the new pattern of opening up to the outside world, realize coordinated development, the free flow and optimal allocation of resource elements, and effective connection with the global industrial chain. The focus of the business environment reform in the Bay Area is to establish a unified list of government powers, a list of responsibilities, a negative list system, full authorization and a convenient business registration system to further promote the internationalization, legalization and facilitation of the business environment, the improvement of which in the Bay Area will help the Guangdong Free Trade Zone to strengthen the mechanism docking, fully integrate international rules and international practices, enhance the level of market integration, and accelerate the attraction of world-class talents and technologies to the Free Trade Zone. As a result, the business environment of the Free Trade Zone will be further optimized.

TABLE III. MAIN ACHIEVEMENTS IN THE BUSINESS ENVIRONMENT OPTIMIZATION OF THE THREE REGIONS OF GUANGDONG FREE TRADE ZONE AND THE BAY AREA OF GUANGDONG, HONG KONG AND MACAO

\begin{tabular}{|c|c|}
\hline Area & Introduction to the main links of business environment optimization \\
\hline Qianhai & $\begin{array}{l}\text { Under the CEPA framework, it is the first to relax the restriction of upper limit of foreign-funded shareholdings of financial institutions; } \\
\text { artificial intelligence and blockchain technology are the first to be applied to the financial sector; and efforts are made to create the "Hong } \\
\text { Kong-Shenzhen International Logistics Corridor". }\end{array}$ \\
\hline Nansha & $\begin{array}{l}\text { implementing full electronic business registration system of"artificial intelligence + robot" ; efficient approval system of"one seal" } \\
\text { managing } 76 \text { major item } 143 \text { sub-item. investment construction project approval compressing to } 25-45 \text { working days to complete. }\end{array}$ \\
\hline Hengqin & $\begin{array}{l}\text { Introduce the management model of "Integrity Store" in Macao; explore the "first payout" system; explore financial innovations such as } \\
\text { intellectual property pledge financing; implement a new model of "property city" governance. }\end{array}$ \\
\hline Bay Area & $\begin{array}{l}\text { Full implementation of the registration and facilitation reform; orderly promotion of the "Securitization Separation" reform pilot; } \\
\text { Guangzhou,Zhuhai, Dongguan,Zhaoqing and other places adopt "government and bank cooperation" to extend the business service } \\
\text { window; realize Hong Kong and Macao investor business registration on-site and remote processing; The number of business start-ups has } \\
\text { been reduced to five, and the procedures for each link have been further simplified. }\end{array}$ \\
\hline
\end{tabular}


C. The Construction of Guangdong, Hong Kong and Macao Bay Area Is Conducive to Further Innovation of Guangdong Free Trade Zone with Hong Kong and Macao Cooperation Model

"One country, two systems" is the most obvious institutional feature of Guangdong, Hong Kong and Macao Bay Area, the Guangdong, Hong Kong and Macao cooperation is the greatest advantage of the Bay Area and Guangdong Free Trade Zone. Under the new international situation and the anti-globalization trend of countries such as the United Kingdom and the United States, The Bay Area needs to take advantage of Hong Kong and Macao's leading position in international trading rules, professional services, market system construction, English and Portuguese language systems and risk supervision. By creating comanagement and sharing of the Bay Area Cooperation Mechanism, we will continue to promote and deepen the comprehensive cooperation between Guangdong, Hong Kong and Macao. This is not only the policy need for the country to fully open the "Early and Pilot Implementation" policy, but also the strategic need to build a bridgehead for the 21st Century Maritime Silk Road. The Guangdong Free Trade Zone has realized the liberalization of the exchange of Guangdong, Hong Kong and Macao in 2014. At present, it has also implemented a negative list management model for Hong Kong and Macao investors. In the future, it is necessary to stand at the commanding heights of the construction of the Bay Area to further innovate and cooperate with Hong Kong and Macao. Guangdong Free Trade Zone can accelerate the construction of advantageous industries in Guangdong, Hong Kong and Macao by relying on the integration of the Bay Area, attract and support youths in Hong Kong and Macao to carry out innovation and entrepreneurship activities in the Free Trade Zone, and strengthen exchanges and cooperation between youths in these three areas to make Guangdong Free Trade Zone a functional platform and demonstration zone for talent cooperation between Guangdong, Hong Kong and Macao. Secondly, the Guangdong Free Trade Zone with Hong Kong and Macao cooperation model innovation should also follow the basic principles of coordinated development, continue to expand the two-way opening and connectivity of the mainland and Hong Kong and Macao market elements, forming the core circle of cooperation between Guangdong, Hong Kong and Macao with Hong Kong as the leader and Nansha, Qianhai and Hengqin as the nodes, further enriching the central function and connotation of the Free Trade Zone, and taking the lead in constructing economic and trade operating rules and systems with Chinese characteristics and in line with international practices in Guangdong, Hong Kong and Macao.

\section{CONCLUSION}

Guangdong, Hong Kong and Macao Bay Area and Guangdong Free Trade Zone are two-way linkage and common development. The experience of institutional innovation, internationalization, legalization and marketization accumulated in the reform and exploration of the Guangdong Free Trade Zone can be replicated in the Bay area. And further coordination between the nine cities of the Pearl River Delta and Hong Kong and Macao should be increased to create an upgraded version of Guangdong, Hong Kong and Macao Bay Area-a combination of Guangdong, Hong Kong and Macao Free Trade Ports. The "small incision" of the Free Trade Zone will lead a "big breakthrough", making the Bay Area as the vanguard and experimental field for the country's comprehensive opening to the outside world and deep participation in the global economic governance structure. The introduction of the major national strategy of Guangdong, Hong Kong and Macao Bay Area has brought new and greater development opportunities for the Guangdong Free Trade Zone, the function of which is the deep cooperation demonstration zone of Guangdong, Hong Kong and Macao, and the core support point of the Bay Area. The strategy of the Bay Area can inject a new impetus to the Guangdong Free Trade Zone to promote institutional innovation, stimulate the vitality of market players, and gather high-end production factors from a higher perspective and a larger pattern to enable the Free Trade Zone to achieve a truly national orientation of "test for the national system, serve for local development". Under the new background of the super-zone between the Free Trade Zone and the Bay Area, Guangdong should grasp the historical opportunity of the two-way linkage development between the Bay Area and the Free Trade Zone, deepen "One Belt, One Road" international space, and gradually improve the right to speak of global economic governance.

\section{REFERENCES}

[1] Yang Wang. Promote the formation of a new pattern of comprehensive openness [N]. People's Daily, 2017-11-10 (04).

[2] Chimeng Cai. Strategic Significance and Realistic Challenges of Urban Agglomeration Construction in Bay Area of Guangdong, Hong Kong and Macao [J]. Guangdong Social Sciences, 2017. (4).

[3] Jiang Lin. Guangdong Free Trade Zone to create an upgraded version of the new platform for opening up to the outside world $[\mathrm{J}]$. China Finance, 2015. (12).

[4] Jiang Lin, Qin Fan. Guangdong Free Trade Zone: Construction Background and Operational Basis [J]. Guangdong Social Sciences, 2015. (3).

[5] Guangyi Lv. From "Three districts linkage" to "Bay Area linkage" Guangdong, Hong Kong and Macao Bay Area linkage development should play the role of the free trade zone engine $[\mathrm{N}]$. Economic Information Daily, 2018-2-2 (005).

[6] Guiling Lu. Guanghan Chen elaborates the strategy of Guangdong, Hong Kong and Macao Bay Area. From infrastructure interoperability to future innovation and development $[N]$. Shanghai Securities News, 2017-7-19 (006).

[7] Fan Wang. Tightly grasp the new opportunities in Guangdong, Hong Kong and Macao Bay Area. Guangdong Free Trade Zone seeks to break through again [N]. 21st Century Business Herald, 2018-5-18 (008).

[8] Jun Wang, Jun Yuan. Guangdong, Hong Kong and Macao Bay Area Construction Report (2018) [R]. Beijing: Social Sciences Academic Press, 2018. 